\title{
ANALYSIS OF MEASURED AND PREDICTED LAND SURFACE SUBSIDENCES CAUSED BY RETREAT MINING
}

\author{
TADEUSZ MAJCHERCZYK, KATARZYNA KRYZIA \\ AGH University of Science and Technology, Kraków, Poland. \\ E-mail: majcher@agh.edu.pl
}

\begin{abstract}
This article presents the impact of the retreat mining (i.e., involving an intended collapse of the excavation roof, subsequent to extraction) on the subsidence of the ground surface. The analysis was carried out for two areas of coal underground mining located in the Upper Silesian Coal Basin (Górnośląskie Zagłębie Węglowe). The assessment of the influence of exploitation on the ground surface was based on the results of geodetic measurements performed over a long period of time, whereas the land deformation prediction was made with the use of the EDNOPN program. The calculated and the predicted values were further compared, and the parameters of theory were determined. The results discussed in this paper have been shown by way of diagrams. The observed differences in the processes of vertical displacement were used in the analysis which took into account the degree to which the rock mass had been disturbed during the previous excavations, as well as the type of incumbent rock in the area under study.
\end{abstract}

\section{INTRODUCTION}

The nature of deformation of ground surface caused by exploitation depends, to a great extent, on the geological and mining conditions. That process is long-lasting and changeable over time, which is particularly visible in multi-seam mining. The room and pillar mining (retreat mining) effects in the changes on the surface of the ground, which take the form of settlement or other settlement-related phenomena called deformation indexes. The alteration in the conditions accompanying mining works has the impact on the kinetics of the deformation process [3], [10]. Currently, reliable information on the influence of mining on the ground surface is obtained by means of geodetic methods, or satellite measurements. It is common to use the methods of geodetic leveling in the excavation areas, which make it possible to determine the subsidence of the reference points. The settlement values, obtained through measurement, enable one to verify the predicted deformations and to determine the socalled parameters of theory [8], [9].

This paper presents two case studies of multi-seam mining, which were monitored by way of geodetic measurements over a long period of time. The obtained results made it possible to prepare a re-prediction of the settlement distribution. 


\section{GEOLOGICAL AND MINING FEATURES OF THE AREA UNDER STUDY}

The analysis of the measured values of ground surface subsidence and the identification of theoretical parameters were carried out for two case studies, in which the deposits were exploited by means of the method of room and pillar mining.

\subsection{CASE STUDY 1}

In geological profile to the depth of $663 \mathrm{~m}$, the strata of Trias and Carboniferous period were identified. In Trias, as deep as $150 \mathrm{~m}$, there are the strata of limestone, as well as yellow and grey dolomite. Further on, the depth of $173 \mathrm{~m}$, there is a complex of silt and Buntsandstein. The Ruda Beds, saddle beds, and the Poruba Beds were found in the rock mass of the Carboniferous period.

The Ruda Beds consist of a complex of layers of sandstone, clay slate and coal with overall thickness of $150 \mathrm{~m}$. The following seams occur in that complex: seams $412,414,416 / 1,419$, and their thickness varies between $0.15 \div 3.85 \mathrm{~m}$. The series of the saddle beds is about 80 -meters thick and is represented mainly by arenaceous shale and sandstone. Within that complex there are the seams 504, 506, and 510, with the thickness ranging from $0.90 \div 9.70 \mathrm{~m}$.

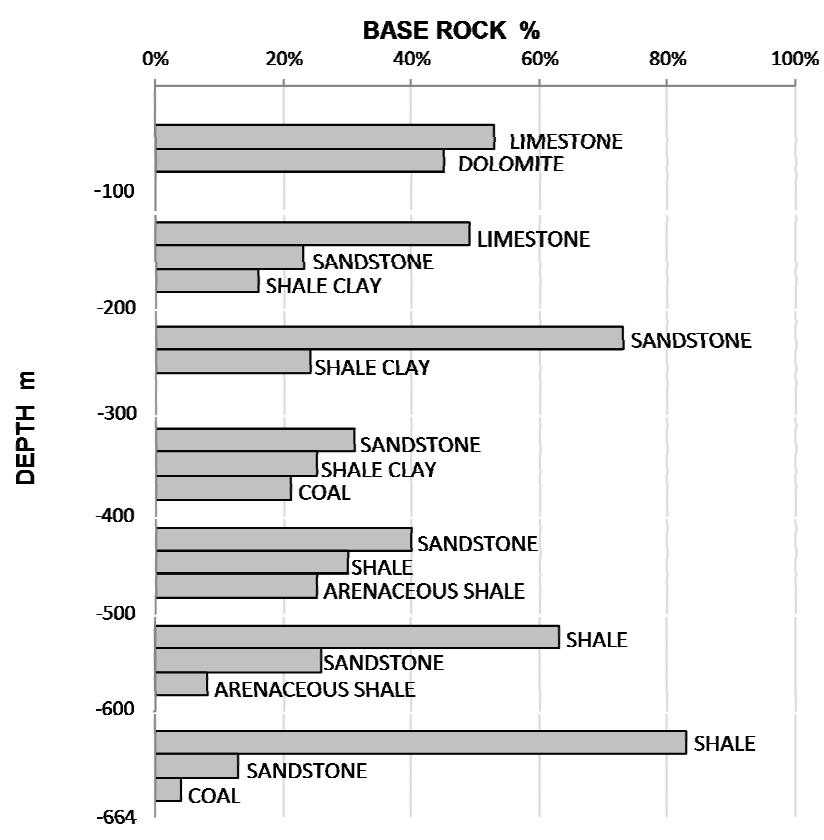

Fig. 1. Participation of different types of rocks in geological profile-Case Study 1 
The Poruba Beds consist in majority of arenaceous shale and sandstone, the thickness of which varies between $0.4 \mathrm{~m}$ and $28.1 \mathrm{~m}$. Within the Poruba Beds complex there are the seams: $606 / 2,615,616,620$, and 622. Percentage share of particular types of layer in $100 \mathrm{~m}$ of the profile is shown in Fig. 1.

In the period under study, i.e., $2005 \div 2011$, exploitation was carried out in 12 longwalls located in four seams: seam 414 wII, longwall 215; seam 506/I, longwall 600 , seam 510 wIII, longwalls $531 \div 535$, seam 615 , longwalls $405 \div 408$ and 408 a. Figure 2 shows the arrangement and shape of particular lots.

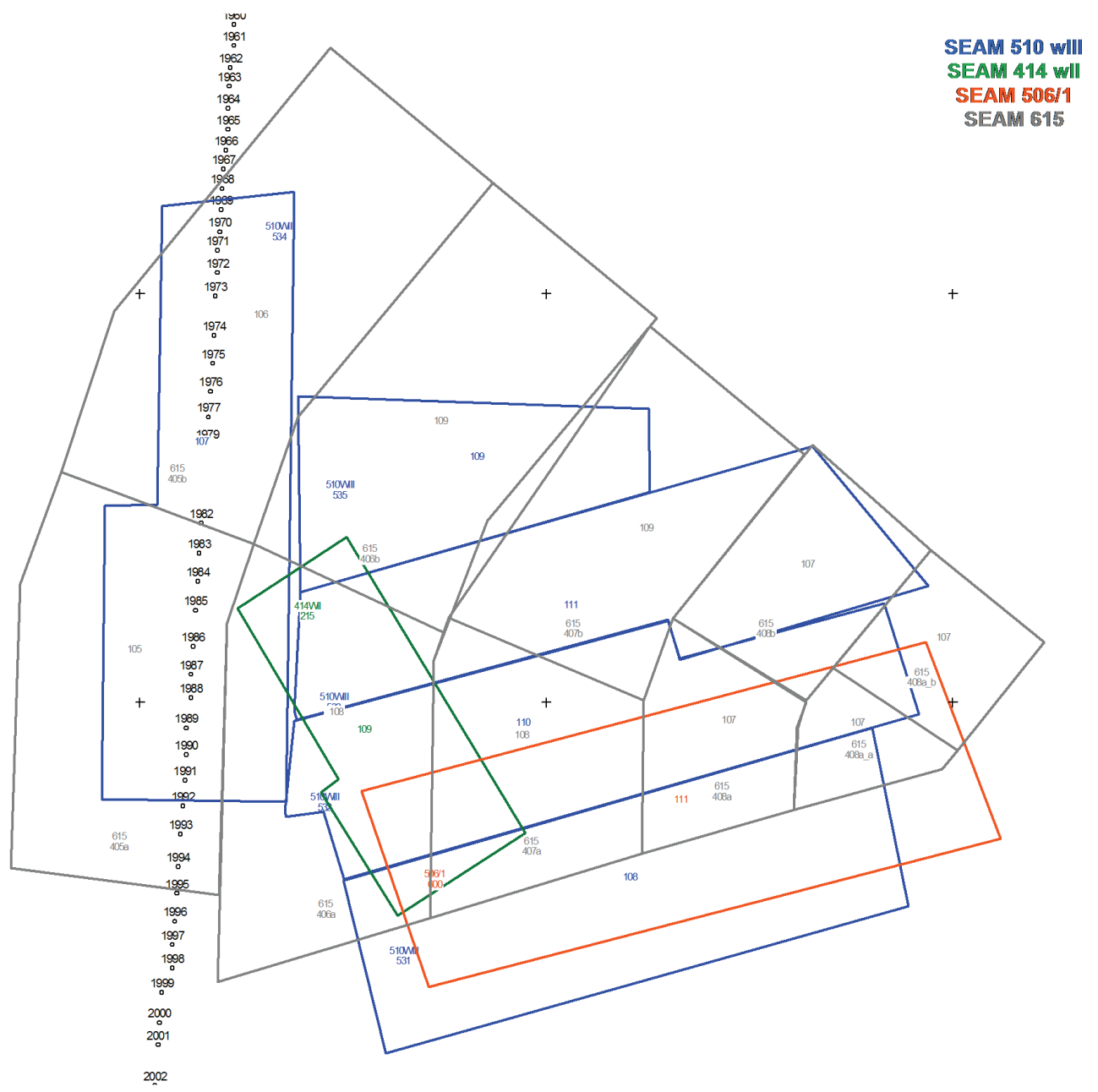

Fig. 2. Location of mining fields in the region analyzed, with the situation of the observation line - Case Study 1 


\subsection{CASE STUDY 2}

In geological profile to the depth of $850 \mathrm{~m}$, there are the deposits of Trias and Carboniferous period. In the complex of the overlay strata to the depth of $31 \mathrm{~m}$, one may discern marl, further to the depth of $150 \mathrm{~m}$ - dolomite, and subsequently, a 24-meter thick layer of limestone and a 20-meter layer of dolomite.

The rock mass of the Carboniferous period comprises the Ruda Beds, saddle beds and the Poruba Beds. The Ruda Beds consist of a complex of clay slates, coal and sandstone, with the thickness of approximately $425 \mathrm{~m}$. The deposits which are present in that complex are the seams $406 \div 419$, whose thickness varies between $0.3 \div 3.0 \mathrm{~m}$. The saddle beds have the thickness of about $130 \mathrm{~m}$ and are mainly represented by clay slates and arenaceous shale. Within that complex there are the seams $501 \div 506$ with the thickness ranging from $0.5 \div 3.6 \mathrm{~m}$. The Poruba Beds are located at the depth of $768 \div 850 \mathrm{~m}$ and they are composed mainly of arenaceous shale and sandstone. Figure 3 features the percentage share of individual rock type layers in $100 \mathrm{~m}$ of the profile.

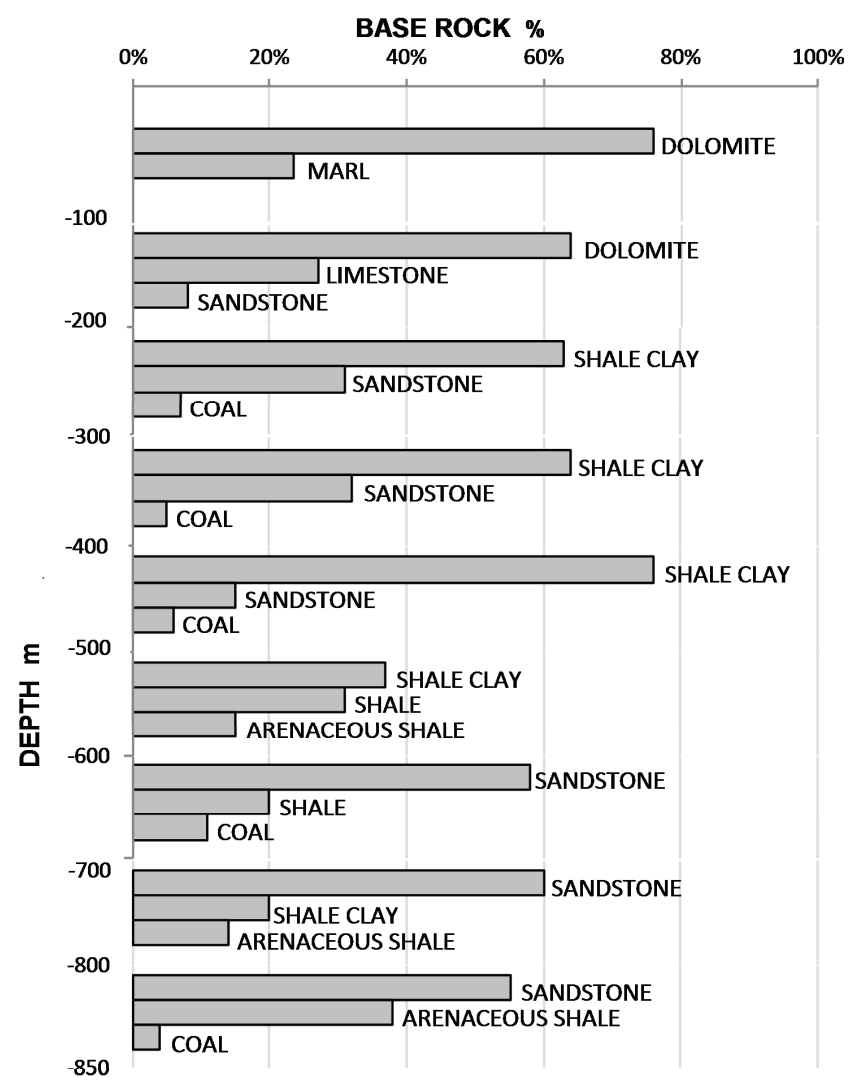

Fig. 3. Participation of different types of rocks in geological profile - Case Study 2 
In the period under scrutiny, i.e., from 1987 to 2010, the excavation was carried out in 45 longwalls situated in 8 seams: seam 501, longwalls $1 \div 8$; seam 503, longwalls $2 \div 4$ and 35 ; seam 504 , longwall 45 ; seam $507 \mathrm{wg}$, longwalls 10,10 a, and longwalls $72 \div 76$; seam $507 \mathrm{wd}$, longwalls $71 \mathrm{a}$ and $72 \mathrm{a}$; seam $509 \mathrm{wg}$, longwalls $1 \div 5$ and $91 \div 97$, seam 509wd, longwalls 91A, 92A, 97A, 99A; seam 510wg, longwalls 18, 30, 31; seam $510 \mathrm{wd}$, longwalls 18a, 20A, 26, 27, 29. Figure 4 presents the arrangement and shape of particular lots.

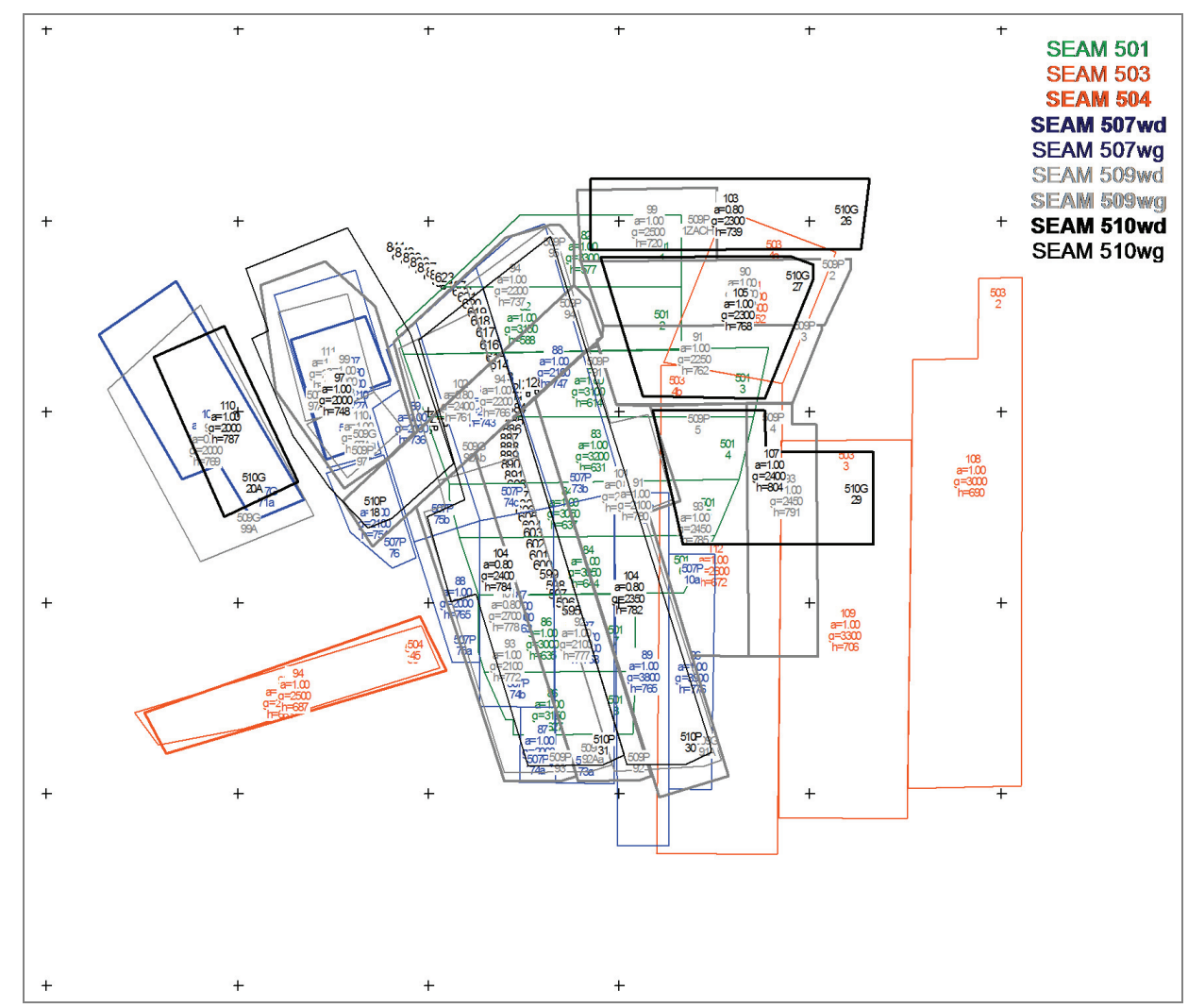

Fig. 4. Location of mining fields in the region analyzed, with the situation of the observation line - Case Study 2

\section{RESULTS OF GEODETIC MEASUREMENTS}

\subsection{CASE STUDY 1}

In the mining area under scrutiny, a south-north observation line was established. The measurements of ground subsidences were taken on that line, at the intervals de- 
pending on the intensity of the deformation process. During the first year, the observations were performed each month, and then - less frequently, several times a year. Those measurements made it possible to analyze the subsidence values in the period between February 2006 and October 2010. As a result of levelling monitoring, it was possible to interpret the course of the deformation process. Figure 5 presents the juxtaposition of the increments of subsidence in particular time intervals.

Over the last five years, the maximum values of ground subsidence amounted to $2.7 \mathrm{~m}$ in $707 \mathrm{~m}$ of the observation line. Particularly large increments of ground subsidence may be observed during the first year of geodetic monitoring: the maximum subsidence value equaled $1.4 \mathrm{~m}$. The subsidence became significantly less intense in the period between January-November 2007, and then became relatively dynamic, especially in the northern part of the observation line, until April 2010. It must be stressed that the values of settlement at the end points of the line of sight tend to fade, both in the northern (the subsidence of $1.5 \mathrm{~m}$ ) and the southern (the subsidence of $0.20 \mathrm{~m}$ ) direction.

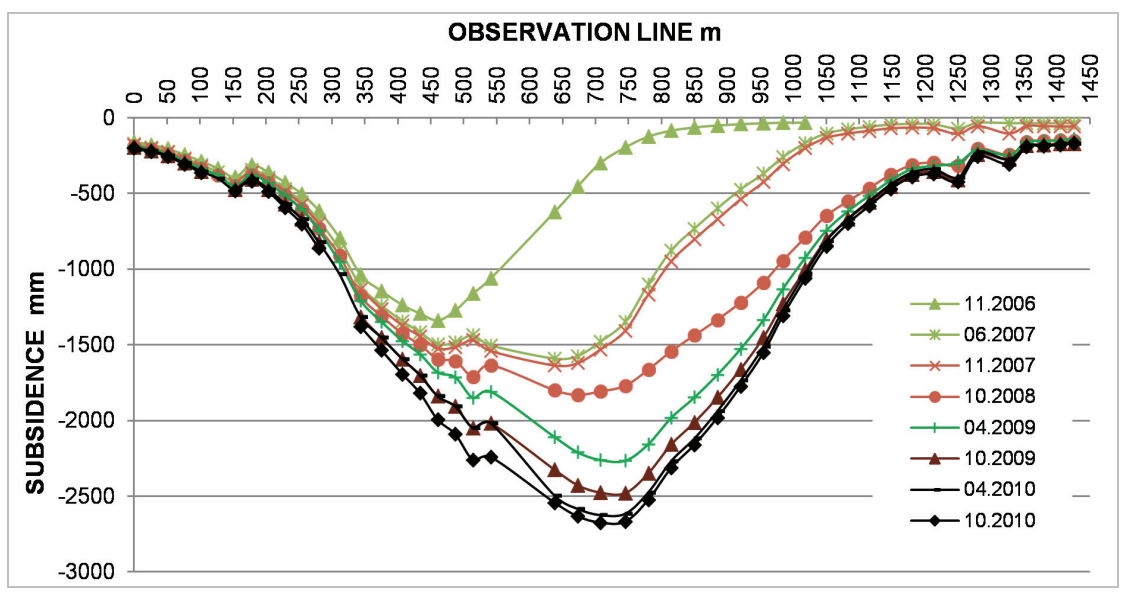

Fig. 5. Ground settlement along the observation line in Case Study 1 - zero (initial) measurement in May 2006

\subsection{CASE STUDY 2}

In the monitored mining area analyzed in the second case study, the north-south observation line was examined. That line ran near housing estates. Ground settlement is measured on that line twice a year, in spring and autumn. Levelling monitoring made it possible to interpret the characteristics of the deformation process. Figure 6 shows the juxtaposition of subsidence increments in particular time intervals.

During the whole period under scrutiny, i.e., from November 1987 to November 2010 , ground settlement reached the value of almost $10 \mathrm{~m}$. The observation line did 
not traverse the boundaries of the exploitation area, therefore, it was impossible to obtain the picture of the entire subsidence trough.

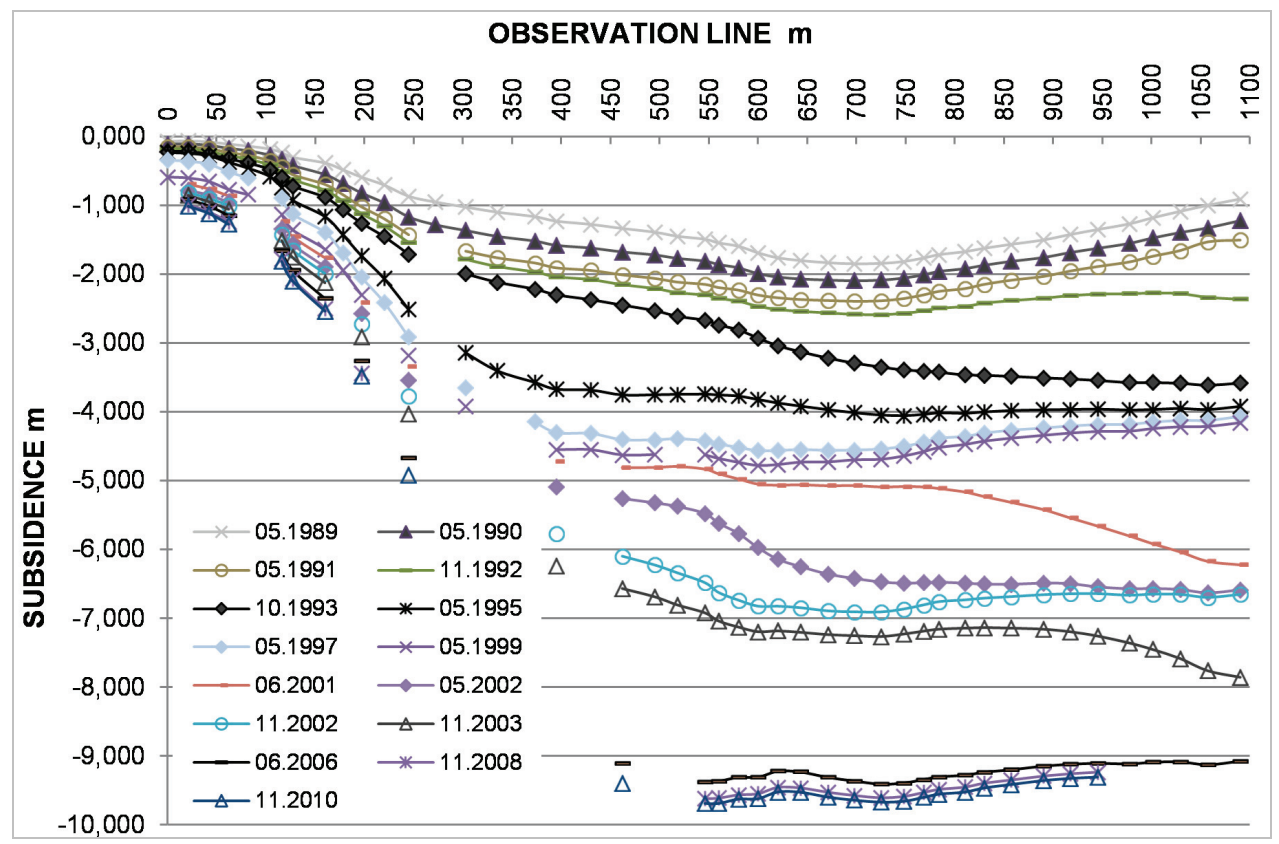

Fig. 6. Ground settlement along the observation line in Case Study 2 - zero (initial) measurement in November 1987

\section{ANALYSIS OF TEST RESULTS}

The results of the fitting of the theoretical subsidence with the values measured in the retreat mining area were analyzed on the example of the above mentioned two case studies. In the first area, the excavation was carried out in the safety pillar, and in the second case - in the rock mass disturbed by previous extraction. The prediction of deformation was made using the EDNOPN program, in accordance with the Knothe theory [1], [2]. The results of the analysis have been illustrated by means of diagrams.

\subsection{DETERMINING THE PARAMETERS OF THEORY IN CASE STUDY 1}

The parameters of the Knothe theory were determined by way of predicting the values of settlement of the points which corresponded with the situation of the observation line on which the geodetic measurements were taken. Those parameters were determined for two time intervals, i.e., in the periods of $05.2006 \div 10.2008$ and $05.2006 \div 10.2010$. 
Figure 7 displays the actual subsidence on the observation line, and the calculated predictions in $05.2006 \div 10.2008$. The best fit was obtained for the parameter of theory $\operatorname{tg} \beta$ equal to 1.8 and the exploitation index of 0.8 . It is noteworthy, however, that the maximum value of the settlement obtained from the measurements in the period under analysis amounts to about $1.8 \mathrm{~m}$, whereas the predicted value was $2.25 \mathrm{~m}$. The largest difference between the forecasted and the measured subsidence is almost $0.75 \mathrm{~m}$ and is located in the $800 \div 850 \mathrm{~m}$ section of the observation line.

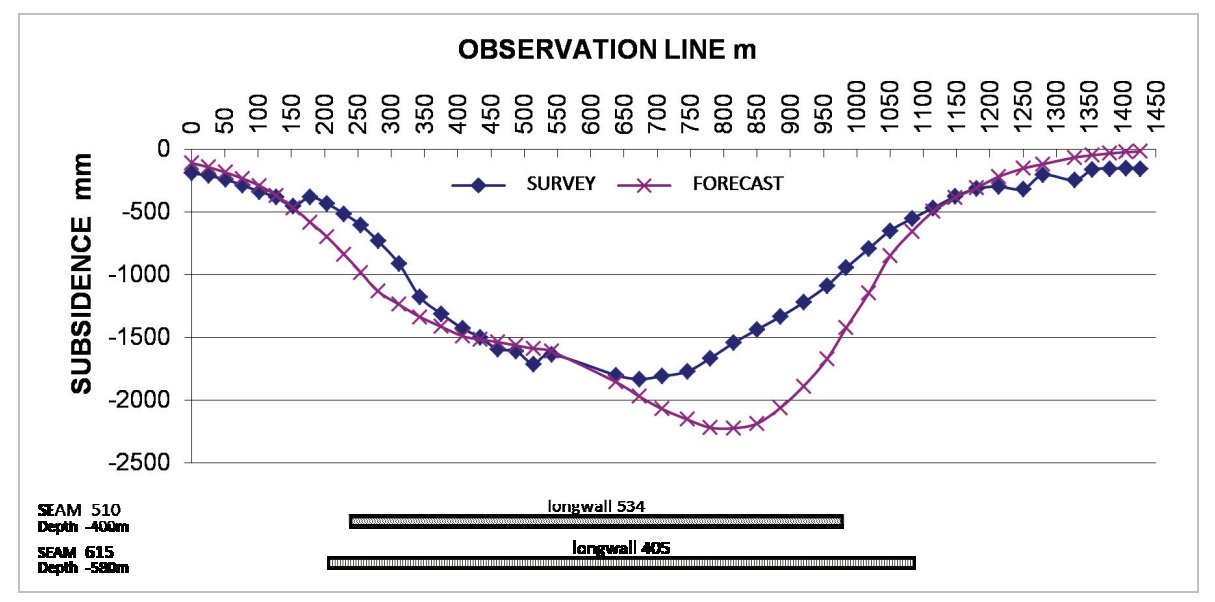

Fig. 7. Measured and predicted subsidence $05.2006 \div 10.2008$

The obtained values were directly influenced by the two walls exploited beneath the observation line. Longwall 534 in seam 510 wIII was exploited at the depth of $400 \mathrm{~m}$ in the period of $07.2006 \div 03.2007$, from north to south, whereas longwall 405 in seam 615 was exploited at the depth of $580 \mathrm{~m}$ in $07.2005 \div 06.2006$, from south to north. The subsidence of the points on the observation line in that period was also triggered by the extraction carried out in four walls to the east of the observation line in seam 615 and one longwall in seam 510 wIII. Mining in that area took place with the use of safety pillars, therefore the rock mass was not disturbed by the multi-seam excavation.

The reason behind the differences between the measured and the calculated values should be searched for in the exploitation of seam 615 , carried out in the time interval analyzed, parallel to the observation line but not directly beneath it. Owing to the lack of explicit disturbance of the rock mass due to excavation, it must be supposed that the impact of the extraction did not become visible on the surface of the ground.

That fact is confirmed by the analysis of the subsequent period of monitoring, i.e., $05.2006 \div 10.2010$. The results of predictions for the angle of impact range $\operatorname{tg} \beta=1.8$ and the exploitation index $a=0.8$ point to a large convergence with the results of measurements (Fig. 8). The displayed values of theory parameters are presented in literature as the basic parameters for an undisturbed rock mass [4], [5]. 
The maximum measured value of subsidence equals $2.7 \mathrm{~m}$, with the predicted value of $2.6 \mathrm{~m}$. The maximum difference (positive or negative) is visible on the sides of subsidence trough and amounts to about $0.3 \mathrm{~m}$, which is an error within the limit of $12 \%$. Small value of subsidence increments in that period results mainly from the exploitation of six longwalls in seams: $414 \mathrm{wII}, 510 \mathrm{wIII}$, and 615 , situated to the east of the observation line.

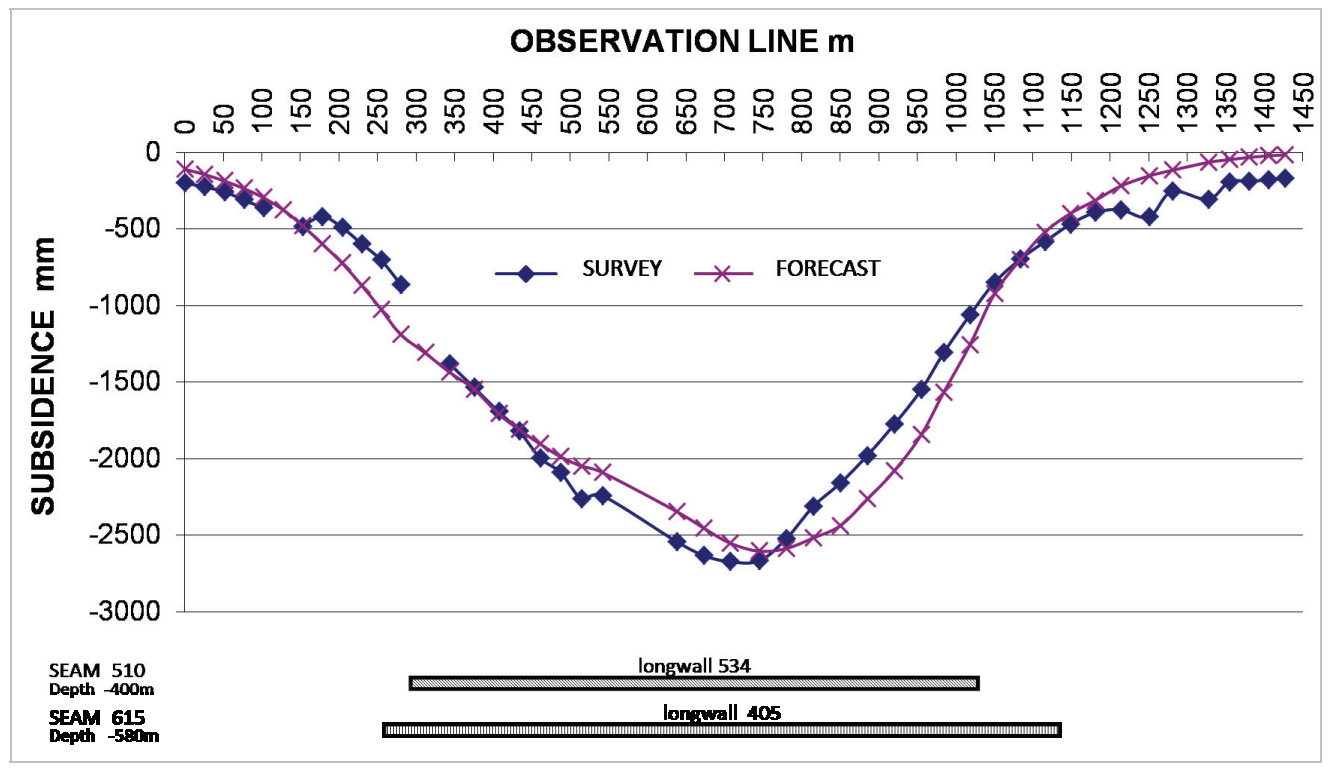

Fig. 8. Measured and predicted subsidence in the period of $05.2006 \div 10.2010$

The performed analysis shows that the parameters from the Knothe theory, assumed for the purpose of re-prediction, provide a very good description of a rock mass only slightly disturbed by previous excavation, and composed, in the prevailing part of the profile, of compact sandstone, limestone and dolomite. The type of rocks might be also the reason behind the delayed manifestation of the impact of mining on the ground surface. [6].

\subsection{DETERMINING THE PARAMETERS OF THEORY IN CASE STUDY 2}

For the second area the same methodology was used: the measured and the predicted values were compared by determining the parameters of the Knothe theory. The results of geodetic measurements, used in the analysis, come from a long time span, i.e., from 11.1987 to 11.2010 . For the purpose of analysis, that time was divided into 
three periods during which the excavation was carried out directly beneath the observation line, i.e., $11.1987 \div 11.1990,11.1990 \div 11.1995$ and $11.2000 \div 11.2005$. However, it must be added that in the area under investigation the impact of excavation has manifested itself on the ground surface ever since the first half of the 20-th century, as a result of mining in several beds. Hence, Case Study 2 describes a typical instance of a rock mass severely disturbed by excavation.

In the first of the periods investigated, ie., from November 1987 to November 1990, the maximum deformation equaled $2.28 \mathrm{~m}$, whereas the predicted one was $2.1 \mathrm{~m}$ (Fig. 9). The parameters assumed in prediction for that area had the following values: angle of impact range $\operatorname{tg} \beta 2.0$, and the exploitation index $-a=1.0$.

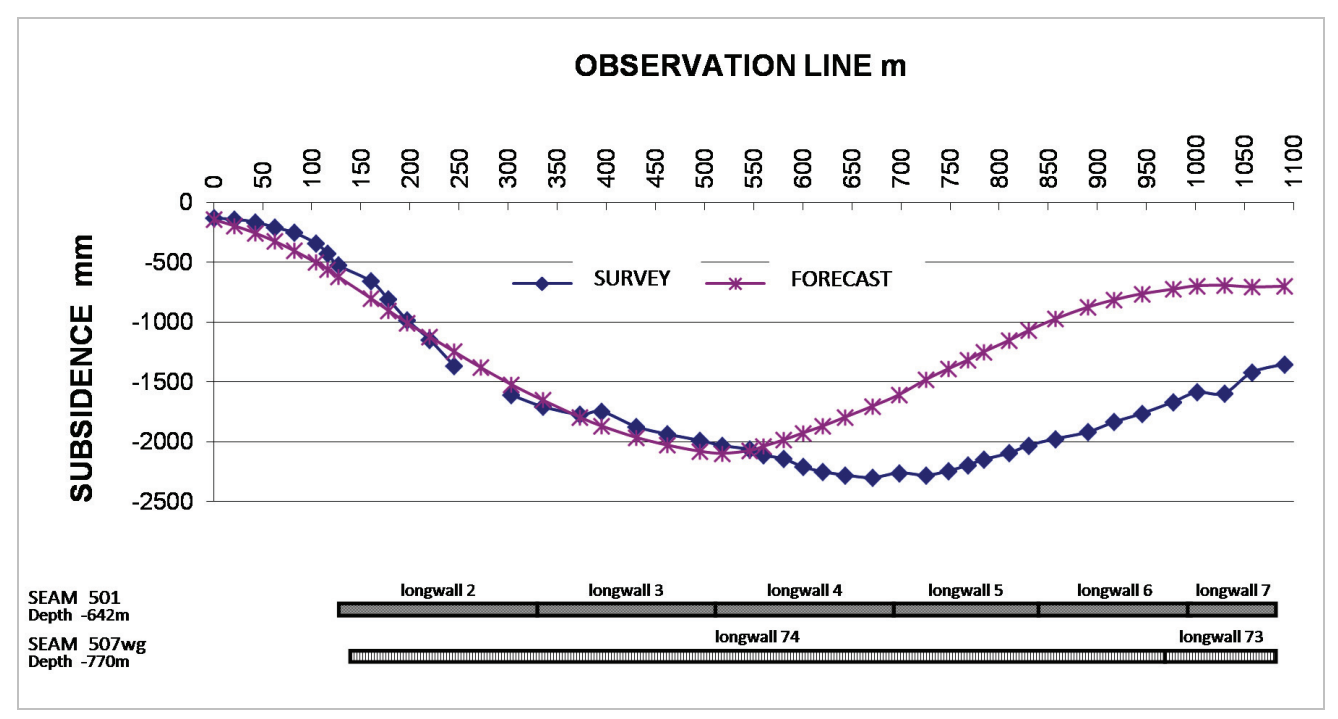

Fig. 9. Measured and predicted subsidence in the period of $11.1987 \div 11.1990$

On the basis of Fig. 9 it is possible to conclude that there is a large discrepancy between the measurement and the prediction on the right side of the subsidence trough. In the period analyzed, seam 507wg was exploited in six longwalls located directly underneath the observation line or in its close proximity. In addition, seam $509 \mathrm{wg}$ was exploited in two longwalls situated north-east off the observation line. The discrepancies may have resulted from the reactivation of the abandoned excavations in seam 501, extracted until the end of 1986, as well as from the assumed value of the ratio of time in which the impact becomes visible.

The above thesis is confirmed by the analysis of the subsequent period, i.e., $11.1990 \div 11.1995$ (Fig. 10). In that case the prediction is most similar to the measurements, when the assumed angle of impact range $\operatorname{tg} \beta$ equals 2.0, and the exploitation 
index for the walls extracted during that time, directly under the observation line, $a=1.15$, and for the remaining ones $a=1.0$. Such high exploitation indices are caused by previous excavation in a disturbed rock mass. The most significant impact on the measured deformations should be attributed to the longwalls located in seam $509 \mathrm{wg}$, situated beneath the observation line, starting with the 130th meter till the end of its length. The obtained maximum values of subsidence from the prediction amounted to $2.2 \mathrm{~m}$, whereas the measured ones equaled $2.6 \mathrm{~m}$.

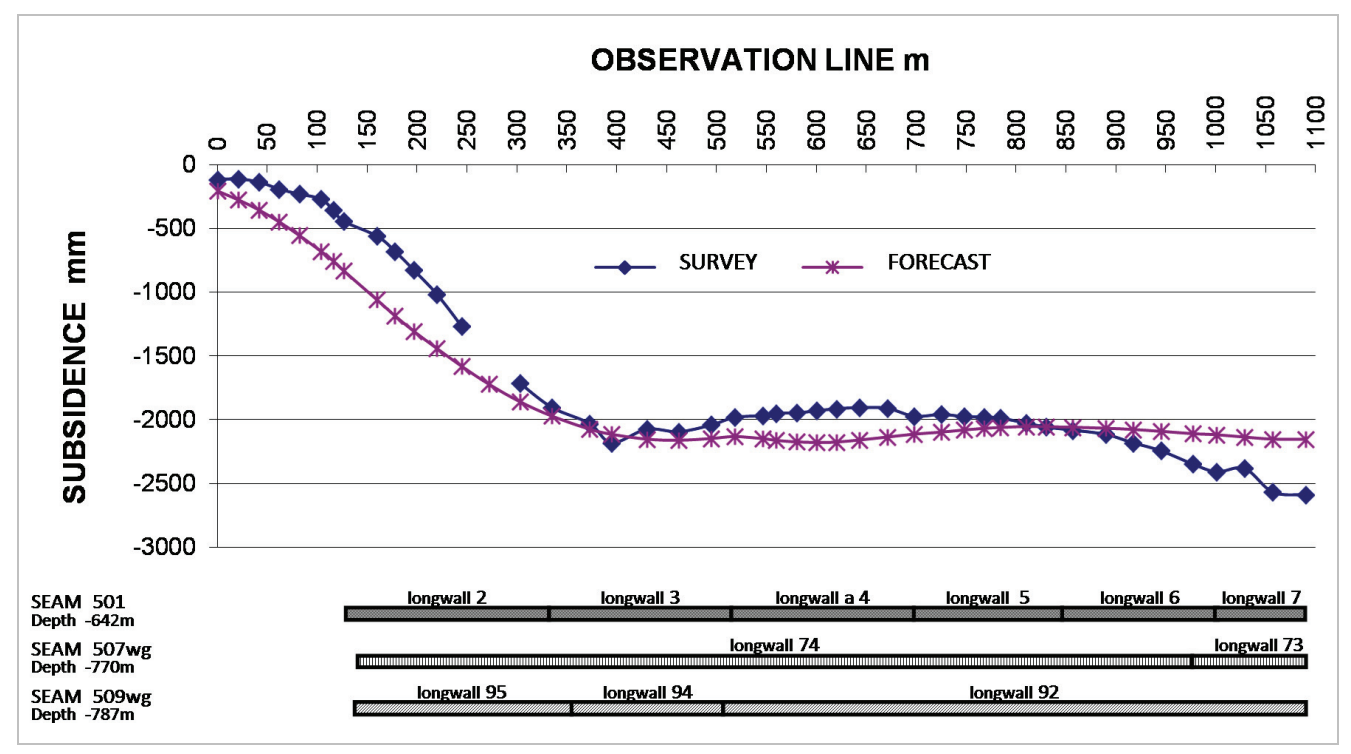

Fig. 10. Measured and predicted subsidence in the period of $11.1990 \div 11.1995$

In the area under study, further excavation directly under the observation line was carried out in the period of $11.2000 \div 11.2005$ (Fig. 11). The extraction took place in longwalls $91 \mathrm{~A}$ and $92 \mathrm{~A}$ in seam $509 \mathrm{wd}$, and longwalls 30 and 31 in seam $510 \mathrm{wg}$. It was also carried out in other seams, the longwalls of which were located further off the observation line, i.e., bed 507wd and seam 510wd. Part of the longwalls was extracted by means of the room and pillar mining method (retreat mining) in which, after the roof of the excavation was allowed to collapse, the goaf was tightened with additional material. For the purpose of making prediction, the exploitation index was assumed to be equal to $a=0.8$. The remaining parameters of the Knothe theory were left unchanged, as compared with the previous time intervals. In the case under study, the maximum values of settlement approximate the prediction and the measurements, and amount to about $4.6 \mathrm{~m}$. One may, however, notice a significant difference towards the end of the observation line. The predic- 
tion, in this case, gives $3.5 \mathrm{~m}$, but the measurements of the deformation shows the maximum value of as much as about $4.5 \mathrm{~m}$. The reason behind those differences may be the reactivation of abandoned excavations or wrongly assumed time ratio.

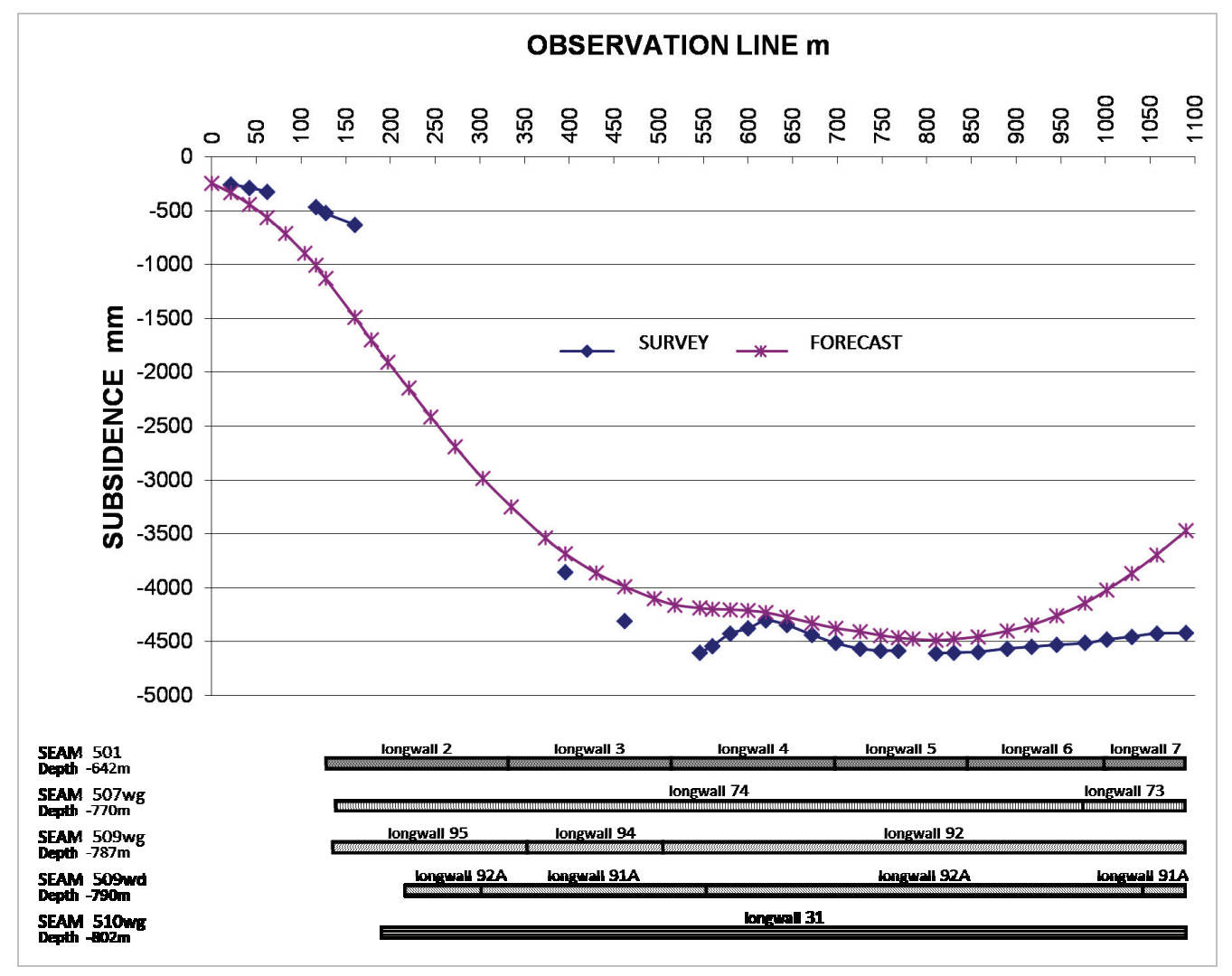

Fig. 11. Measured and predicted subsidence in the period of $11.2000 \div 11.2005$

When we analyze the re-prediction of the ground surface of the mining area, it must be stated that in each of the periods under study the results of deformation measurement are higher than the calculated values. Such differences were obtained even when the exploitation index was assumed as $a=1.15$ for the longwalls extracted directly under the observation line. That could be explained by the fact that the old excavations might have reactivated due to the rock types in geological profile: a large proportion of compact dolomite in the sub-surface layers, together with a large proportion of sandstone strata in the immediate surroundings of the seams exploited in the periods under study. One may also expect that the impact range on the ground surface will be larger than implied by theoretical considerations, due to multi-seam extraction and a large degree of rock mass disturbance [6], [7]. 


\section{SUMMARY}

The analysis of subsidence measurements and the parameters of the Knothe-Budryk theory, determined on the basis of a re-prediction, made it possible to arrive at the following conclusions:

1. The response of a rock mass to the underground retreat mining is a complex phenomenon, depending to a great extent on the lithological profile and the degree to which the rock mass was disturbed by previous excavation. Both areas under investigation were located in the regions where the incumbent strata, consisting of the Tertiary and the Quaternary rock types, did not exceed the thickness of a dozen or so meters.

2. In Case Study 1, which was related to the excavation in the undisturbed rock mass, the parameters described by the following values: $a=0.8$ and $\operatorname{tg} \beta=1.8$, often assumed as classic ones, provided a very good description of ground settlement.

3. Case Study 2 described the area which was severely disturbed by multi-seam excavation over a long period of time. An attempt at re-prediction proved difficult, since even though the exploitation index was assumed as slightly higher than 1.0, the value of subsidence obtained from calculations was smaller than the measured one.

4. The discrepancies between the re-prediction and the measurements in the case of multi-seam excavation result largely from the disturbance of the rock mass, as the excavation-related dislocation planes are changeable and they diverge considerably from the typically assumed $\operatorname{tg} \beta=1.8 \div 2.0$. Moreover, due to the presence of compact rock types in geological profile, the traits of previous exploitation tend to manifest themselves to a greater extent. The settlement value corresponding with the exploitation index within the limit of 1.0 was obtained also due to the fact that the excavation took place subsequently on the seams located at a small distance from one another, or that the seams were exploited layer after layer.

The paper was prepared on the basis of the contract in AGH, no. 15.11.100.705.

\section{REFERENCES}

[1] BiAŁEK J., Algorithms and computer programs for the prediction of mining ground deformation, (in Polish), Algorytmy i programy komputerowe do prognozowania deformacji terenu górniczego, Wydawnictwo Politechniki Śląskiej, Gliwice, 2003.

[2] BIAŁEK J., Comments on the assessment methodology exploitation influence of mining on the objects of the mining area, (in Polish), Uwagi na temat metodyki oceny wplywu eksploatacji górniczej na obiekty terenu górniczego, X Dni Miernictwa Górniczego i ochrony terenów górniczych, Kraków, 2010.

[3] KNothe S., Forecasting exploitation influence of mining, (in Polish), Prognozowanie wplywów eksploatacji górniczej, Wydawnictwo „Śląsk”, 1984.

[4] KowALSKI A., Examples of comparison of forecast and measured surface deformation indices, (in Polish), Przykłady porównania prognozowanych z pomierzonymi wskaźnikami deformacji powierzchni, Przegląd Górniczy, No. 7-8, 2008. 
[5] KwIATEK J., Objects civil engineering in mining area, (in Polish), Obiekty budowlane na terenach górniczych, Wydawnictwo Głównego Instytutu Górnictwa, Katowice, 2007.

[6] MajcherczyK T., Niedbalski Z., Kryzia K., Changes to the range of exploitation impact when mining the next coal deposit on the basis of geodetic measurements, AGH, Journal of Mining and Geoengineering, Vol. 36, No. 1, 2012.

[7] MielimąKa R., The influence of longwall exploitation order and direction on the mining terrain deformation, (in Polish), Wpływ kolejności i kierunku eksploatacji prowadzonej frontami ścianowymi na deformacje terenu górniczego, Wydawnictwo Politechniki Śląskiej, Gliwice, 2009.

[8] PopioŁeK E., Protection of mining areas, (in Polish), Ochrona terenów górniczych, Wydawnictwa AGH, Kraków, 2009.

[9] Rogusz Z., Variaton of parameter $\operatorname{tg} \beta$ in the $S$. Knothe-W. Budryka theory in conditions with seam extracted with caving in a disturbed and undisturbed rock body, (in Polish), Zmienność parametru tg $\beta$ teorii S. Knothego-W. Budryka $w$ warunkach eksploatacji poktadów z zawatem stropu $w$ górotworze naruszonym i nienaruszonym, Prace GIG, Komunikat nr 714, 1980.

[10] STRZAŁKOWSKI P., Outline protection of mining areas, (in Polish), Zarys ochrony terenów górniczych, Wydawnictwo Politechniki Śląskiej, Gliwice, 2010. 